\title{
Efficient Extraction of RNA and Analysis of Gene Expression in a Long-Term Taxus Cell Culture Using Real-Time RT-PCR
}

\author{
Li-Qin $\mathrm{Li}^{\S}$, Chun-Hua Fu${ }^{\S}$, Chun-Fang Zhao, Juan Xia, Wen-Juan Wu, and \\ Long-Jiang $\mathrm{Yu}^{*}$
}

Department of Biology Science and Technology, Huazhong University of Science and Technology, Wuhan, 430074, Hubei, China. Fax: +86-27-87792265.

E-mail: yulj@mail.hust.edu.cn

* Author for correspondence and reprint requests

Z. Naturforsch. 64c, 125-130 (2009); received April 23/June 30, 2008

A simple, quick and efficient method for isolating total RNA from heavy browning cells was developed by adding polyvinylpyrrolidone, mercaptoethanol and $3 \mathrm{~m} \mathrm{NaAc}$ during the process of the Trizol (a kind of a widely used RNA extraction buffer) method. High-quality total RNA was isolated and synthesized to cDNA. Transcript levels of four paclitaxel biosynthetic pathway genes: $d x r$, hmgr, ggpps and dbat were assayed by real-time RT-PCR. The results demonstrated that the transcript levels of these genes experienced a coincident descent in the past three years as well as a decreasing paclitaxel productivity. According to these results, the possible reason for the descending paclitaxel productivity during long-term Taxus media cv. Hicksii cell culture maybe due to a decreasing transcripts level of mass genes in close with a gross secondary metabolite level. Gene manipulation emphasized only on key enzyme genes in the paclitaxel biosynthesis pathway may not hamper the somaclonal variation trend of Taxus media cv. Hicksii cell culture.

Key words: RNA Extraction, Taxus, Real-Time RT-PCR

\section{Introduction}

Many secondary metabolites derived from plants are used as pharmaceuticals, among which paclitaxel, the most successful anticancer drug, was initially approved for the treatment of breast and ovary cancers. However, the use of this drug is restricted due to limited production.

Huge efforts have been made to develop a more sustainable source of paclitaxel. However, the complex structure of paclitaxel has impeded the development of a method to enhance its synthesis (Chau et al., 2004). At present, the commercial production is semi-synthesis by using precursors (e.g. baccatin III) extracted from natural sources. However, with the increasing usage of paclitaxel for the treatment of additional cancer types and other human diseases, environmental problems of the semisynthesis still exist (Pyo et al., 2004). Another alternative is a plant cell suspension culture, which has several advantages: This method is similar to well established procedures that have been used successfully in bacterial fermentation. It facilitates basic studies on the paclitaxel biosynthesis; it ap-

\footnotetext{
$\S$ These authors contributed equally to this work.
}

pears to accumulate compounds not found in natural abundance in the bark and needles of plants. This process can provide an environmentally friendly methodology to receive a highly pure product.

However, a major obstacle for developing largescale production systems based on plant cells was the instability of metabolite accumulation. Several reports showed a gradual loss of the secondary metabolite production ability, inconsistent production patterns or high variation in yield (Smykal et al., 2007; Trejo-Tapia et al., 2008). Somaclonal variation has also been observed during long-term Taxus cell culture. Previous research in our lab showed that a young cell line newly derived from Taxus media cv. Hicksii explants emerged the phenomena of acclimatization during a 4-year conventional subculture. The rate of biomass accumulation becomes faster; cell colour changes from deeply brown to white, and at the same time, paclitaxel production gradually becomes lower. The same phenomenon was reported by Kim et al. (2004). Many efforts have been made to research the somaclonal variation mechanism of long-term plant cell culture (Rubluoa et al., 2002; Martin and Pradeep, 2003; Whitmer et al., 2003). Supposed reasons may include point mutations, rearrange- 
ments in nuclear or organellar DNA, the activation of mobile elements, ploidy or epigenetic changes. Few reports have assessed the mRNA transcription level stability in long-term plant cell culture.

The paclitaxel biosynthesis pathway is complicated. Two distinct routes (the classical mevalonate pathway and a novel mevalonate-independent pathway) are utilized by plants for the biosynthesis of isopentenyl diphosphate, the universal precursor of isoprenoids. 3-Hydroxy-3-methylglutaryl coenzyme A reductase (HMGR) is the first key enzyme in the classical mevalonate pathway. 1-Deoxy-Dxylulose-5-phosphate reductoisomerase (DXR) is the second enzyme in the non-mevalonate pathway, which was also considered as a key enzyme (Nims et al., 2006). Therefore, the abundance of $d x r$ and hmgr may reflect the isopentenyl diphosphate accumulation in Taxus cell lines.

Derived from the isoprenoid precursors isoprenyl diphosphate (IPP) and dimethylallyl diphosphate (DMAPP), geranylgeranyl pyrophosphate (GGPP) is synthesized by geranylgeranyl pyrophosphate synthase (GGPPS). After several steps, highly modified taxane occurs to produce 10 -deacetylbaccatin III (10-DAB) which is then converted to baccatin III by 10-deacetylbaccatin III$10-O$-acetyltransferase (DBAT) (Walker and Croteau, 2000). After at least three other catalysis reactions, paclitaxel is obtained. Therefore, GGPP is involved in the early paclitaxel biosynthesis pathway, and DBAT, as a rate-limiting enzyme, is involved in the late paclitaxel biosynthesis pathway.

Expression level variation of key enzyme genes in the paclitaxel biosynthesis accompanied with a gradual loss in the paclitaxel production has not been shown during long-term Taxus cell culture. To investigate the expression level of key enzyme genes, the quantitative real-time RT-PCR method was established. High-quality total RNA of a Taxus media cv. Hicksii cell line with short-term in vitro culture (TS) and a Taxus media cv. Hicksii cell line with long-term in vitro culture (TL) should be isolated as prerequisite. An efficient method of extracting total RNA from the heavy browning TS cell line was also established in this study.

\section{Materials and Methods}

\section{RNA extraction}

A TS cell sample was derived from explants in May 2003, collected in February 2004 and stored in liquid nitrogen, experiencing a 10-time subculture. During the period of subcultures, the calli grew slowly and developed heavy browning. A TL cell sample was collected in July 2007, after 50 times of continuous subculture derived from explants in May 2003. At that time, cells have been well acclimated without browning. A normal RNA extracting method by Trizol (Invitrogen, Carlsbad, USA) was used in this study. In our preliminary experiments, TL samples easily got high-quality RNA, while TS samples with high levels of phenolic compounds and/or polysaccharides yielded poor-quality RNA or no RNA at all. However, extraction of high-quality RNA was necessary for isolating genes by RT-PCR or investigating gene expression profiles. Four kinds of strategies were used in this study to establish an efficient extraction method which is suitable for heavy browning plant materials with high levels of phenolic compounds and/or polysaccharides.

\section{Modified guanidinium isothiocyanate (MGI) method}

(1) Grind $0.1 \mathrm{~g}$ plant cells in liquid nitrogen with a mortar and a pestle. Then, transfer the powders into an Eppendorf tube. Add $0.3 \mathrm{ml}$ extraction buffer ( $4 \mathrm{~mol} / \mathrm{l}$ guanidinium isothiocyanate, $25 \mathrm{mmol} / \mathrm{l}$ sodium citrate, $\mathrm{pH} 7.0,0.5 \%$ sodium lauryl sarcosinate, $0.1 \mathrm{~mol} / \mathrm{l}$ mercaptoethanol).

(2) Shake the sample violently for $2 \mathrm{~min}$. Add $30 \mu \mathrm{l} 2 \mathrm{~mol} / \mathrm{l} \mathrm{NaAc}$ (pH 4.2), $60 \mu \mathrm{l}$ chloroform/ isoamyl alcohol (24:1) and $300 \mu$ l water-saturated phenol, mix completely, and incubate in a ice bath for $15 \mathrm{~min}$. Centrifuge for $30 \mathrm{~min}$ at $20000 \times g$ at $4{ }^{\circ} \mathrm{C}$.

(3) Transfer supernatants into new sterile tubes. Add 1 volume of alcohol, gently vortex, and incubate for $1 \mathrm{~h}$ at $-20^{\circ} \mathrm{C}$. Centrifuge for $25 \mathrm{~min}$ at $15400 \times g$ at $4{ }^{\circ} \mathrm{C}$.

(4) Resuspend the precipitated pellet with $0.1 \mathrm{ml}$ extraction buffer, add $0.1 \mathrm{ml}$ water-saturated phenol and $40 \mu \mathrm{l}$ chloroform/isoamyl alcohol, and incubate in an ice bath for $10 \mathrm{~min}$. Centrifuge for $30 \mathrm{~min}$ at $15400 \times \mathrm{g}$ at $4{ }^{\circ} \mathrm{C}$.

(5) Transfer the supernatants into new sterile tubes. Add 1 volume of alcohol and $12 \mu \mathrm{l} 2 \mathrm{~mol} / \mathrm{l}$ $\mathrm{NaAc}$, gently mix, and incubate for $30 \mathrm{~min}$ at $-20^{\circ} \mathrm{C}$. Centrifuge for $20 \mathrm{~min}$ at $15400 \times g$ at $4{ }^{\circ} \mathrm{C}$.

(6) Wash the pellet with $75 \%$ ethanol, air-dry and resuspend it in $20 \mu \mathrm{l}$ of DEPC-treated water. 


\section{Cetyltrimethyl ammonium bromide (CTAB) method}

(1) Add 2\% mercaptoethanol and 2\% polyvinylpyrrolidone (PVP) to CTAB extraction buffer (2\% CTAB, $100 \mathrm{mmol} / \mathrm{l}$ Tris-HCl, $\mathrm{pH} 8.0,1.4 \mathrm{~mol} / \mathrm{l}$ $\mathrm{NaCl}, 20 \mathrm{mmol} / \mathrm{l}$ EDTA, $\mathrm{pH} 8.0$ ), and preheat at $65{ }^{\circ} \mathrm{C}$. Add the cell powder after grinding in liquid nitrogen to the extraction buffer, shake the sample violently, and incubate for $30 \mathrm{~min}$ at $65^{\circ} \mathrm{C}$.

(2) Cool down to room temperature, add $0.6 \mathrm{ml}$ chloroform/isoamyl alcohol $(24: 1)$ and extract repeatedly. Centrifuge for $20 \mathrm{~min}$ at $15400 \times g$.

(3) Add 1/10 volume $3 \mathrm{~mol} / \mathrm{l} \mathrm{NaAc}(\mathrm{pH} \mathrm{5.2)}$ and 2.5 volumes concentrated alcohol to the supernatants. Incubate for $2 \mathrm{~h}$ at $-20^{\circ} \mathrm{C}$. Centrifuge for $30 \mathrm{~min}$ at $15400 \times \mathrm{g}$ at $4{ }^{\circ} \mathrm{C}$.

(4) Wash the resultant pellet with $75 \%$ ethanol, air-dry and resuspend it in $20 \mu$ l of DEPC-treated water.

\section{Trizol method}

The extraction was carried out according to the methods of Trizol (a widely used RNA extraction buffer).

\section{Modified Trizol (MT) method}

(1) Grind $0.1 \mathrm{~g}$ plant cells in liquid nitrogen with PVP and transfer them into an Eppendorf tube. Add $1 \mathrm{ml}$ Trizol reagent and $10 \mu \mathrm{l}$ mercaptoethanol. Mix and incubate for 5-10 min at room temperature. Centrifuge for $10 \mathrm{~min}$ at $13200 \times \mathrm{g}$ at $4{ }^{\circ} \mathrm{C}$.

(2) Add $0.2 \mathrm{ml}$ chloroform/isoamyl alcohol $(24: 1)$ to the supernatant. Shake the sample violently and incubate for 5-10 $\mathrm{min}$ at room temperature. Centrifuge for $15 \mathrm{~min}$ at $13200 \times g$ at $4{ }^{\circ} \mathrm{C}$. Then repeat this step.

(3) Add $6 \mu \mathrm{l} 2 \mathrm{~mol} / 1 \mathrm{NaAc}(\mathrm{pH} 5.2)$ and 1 volume isopropyl alcohol to the supernatant. Incu- bate for $10 \mathrm{~min}$ at room temperature. Centrifuge for $10 \mathrm{~min}$ at $13200 \times \mathrm{g}$ at $4{ }^{\circ} \mathrm{C}$.

(4) Wash the pellet with $75 \%$ ethanol, air-dry and resuspend it in $20 \mu \mathrm{l}$ of DEPC-treated water.

\section{RNA quality examination by electrophoresis and spectrophotometric analysis}

To check the integrity of RNA, $3-5 \mu \mathrm{g}$ isolated total RNA was analyzed on $1.2 \%$ formaldehydeagarose denaturing gels to determine the integrity of rRNA bands. $A_{230}, A_{260}$ and $A_{280}$ of the samples were determined by a spectrophotometer.

\section{Quantitative real-time $R T-P C R$}

The cDNA of samples was synthesized by the SuperScriptTM || Reverse Transcriptase (Invitrogen). DyNAmo SYBR Green qPCR kit (Finnzymes, Espoo, Finland) and Rotor-Gene 3000 (Corbett, Sydney, Australia) were used for quantitative real-time PCR. Primer sequences are listed in Table I. 18SrDNA was the house-keeping gene used as endogenous reference; $d x r$, hmgr, ggpps and dbat were objective genes. PCR conditions: 18SrDNA, hmgr: $94^{\circ} \mathrm{C}$ for $25 \mathrm{~s}, 48^{\circ} \mathrm{C}$ for $25 \mathrm{~s}$, $72{ }^{\circ} \mathrm{C}$ for $25 \mathrm{~s}$; ggpps: $94{ }^{\circ} \mathrm{C}$ for $25 \mathrm{~s}, 50{ }^{\circ} \mathrm{C}$ for $25 \mathrm{~s}, 72{ }^{\circ} \mathrm{C}$ for $25 \mathrm{~s} ; d x r, d b a t: 94{ }^{\circ} \mathrm{C}$ for $25 \mathrm{~s}, 46^{\circ} \mathrm{C}$ for $25 \mathrm{~s}, 72^{\circ} \mathrm{C}$ for $25 \mathrm{~s}$. A melting curve was determined at the end of the 45 cycles starting at $65^{\circ} \mathrm{C}$. Primer specificity was monitored using gel electrophoresis and melting curve data. The amount of DXRmRNA, HMGRmRNA, GGPPSmRNA and DBATmRNA normalized to the endogenous reference (18SrDNA) was calculated applying the comparative threshold cycle $\left(\mathrm{C}_{\mathrm{T}}\right)$ method, according to which the amount of target is given by the following expression: target relative quantity $=$ $2^{-\Delta \Delta} \mathrm{CT}$, where ${ }^{\Delta \Delta} \mathrm{CT}=\left(\mathrm{C}_{\mathrm{T} \text {,target }}-\mathrm{C}_{\mathrm{T}, 18 \mathrm{SrDNA}}\right)_{\mathrm{TS}}-$ $\left(\mathrm{C}_{\mathrm{T}, \text { target }}-\mathrm{C}_{\mathrm{T}, 18 \mathrm{SrDNA}}\right)_{\mathrm{TL}}$ (Amoroso et al., 2004).

\begin{tabular}{llc}
\hline Gene & \multicolumn{1}{c}{ Primer sequence $\left(5^{\prime}-3^{\prime}\right)$} & Product [bp] \\
\hline $18 S r D N A$ & $\begin{array}{c}\text { Sense: TGG AGA AAC TGA AGG AGG TA } \\
\text { Antisense: CTT ATT GAA CAG GGT GGC }\end{array}$ & 119 \\
Sense: GCC CAC AAA TCA CAA GGT & 225 \\
$d b a t$ & $\begin{array}{c}\text { Antisense: TTC AGG TCC ACA TTA GCA } \\
\text { Sense: GGG AGG GTG CTC TGT TTG }\end{array}$ & 154 \\
& $\begin{array}{c}\text { Antisense: GTT ACC TGA ACC ACC AGA GG } \\
\text { Sense: CTA AGG GCA TCA CAG ACC }\end{array}$ & 195 \\
& $\begin{array}{c}\text { Antisense: AGA CCT CAG CCT GCT AAC T } \\
\text { Sense: TGG AGA AAC TGA AGG AGG TA }\end{array}$ & 101 \\
& Antisense: CTT ATT GAA CAG GGT GGC & \\
\hline
\end{tabular}

Table I. Primer sequences applied in this study. 
For each sample, the mean threshold cycle of three replications was used for calculations.

\section{HPLC quantification of paclitaxel}

TS and TL samples were collected $20 \mathrm{~d}$ after subculture. The analysis of paclitaxel was performed by HPLC as described previously with slight modification (Zhang and Fevereiro, 2006). In brief, dry samples $(0.1 \mathrm{~g})$ were extracted with methanol/methylenechloride $(1: 1, \mathrm{v} / \mathrm{v})$ with sonication. The methylenechloride phase was separated from the aqueous phase and then evaporated in a rotary evaporator equipped with a condenser for solvent recovery. The residue was resuspended in $1 \mathrm{ml}$ methanol. HPLC (Waters 2695) was carried out using a reverse-phase C18 column at $227 \mathrm{~nm}$ at $25^{\circ} \mathrm{C}$. The mobile phase was methanol/water $(65: 35, \mathrm{v} / \mathrm{v})$. The elution rate was kept at $0.8 \mathrm{ml} / \mathrm{min}$.

\section{Results}

\section{Comparison of different RNA extracting methods}

RNA of TL samples was successfully extracted by all of the methods mentioned above. Except for the MT method, all of the other methods were not

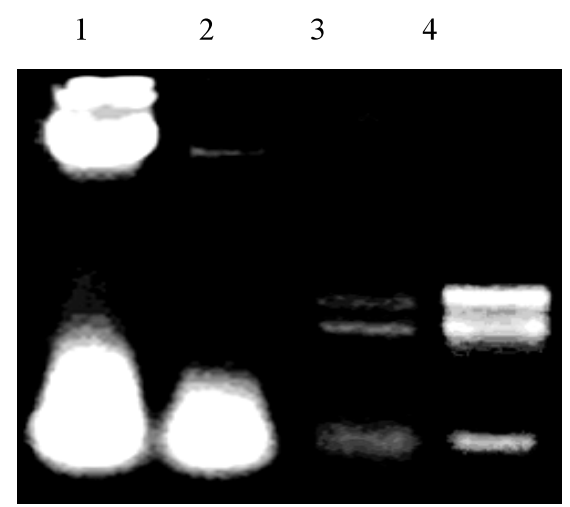

Fig. 1. Different total RNAs of TS samples by four methods. 1, MGI method; 2, Trizol method; 3, CTAB method; 4, MT method. suitable for the TS samples. RNA extracted by the MT and CTAB method can be identified by the presence of 28S, $18 \mathrm{~S}$ and $5 \mathrm{~S}$ bands. The MGI and Trizol method failed to get RNA. RNA extracted via the CTAB method exhibited degradation as shown by weak intensity of $18 \mathrm{~S}$ in comparison with 28S bands (Fig. 1). By spectrophotometric analysis, the $A_{260} / A_{230}$ ratios of RNA extracted by the CTAB method were lower than 1.8 indicating contamination of polysaccharides or polyphenols. RNA extracted by the MT method showed $A_{260} /$ $A_{230}$ ratios above 1.8, and $A_{260} / A_{280}$ ratios ranged between 1.8 and 2 implying little or no contamination of polysaccharides, polyphenol proteins or DNA (Table II). Therefore, relatively satisfactory results are obtained by the MT method, which could be used to obtain high-quality RNA from heavy browning plant tissue or cells.

\section{Transcription levels of dxr, hmgr, ggpps and dbat}

Amplification of the $d x r$, hmgr, ggpps and dbat genes gave specific products of the expected size (Fig. 2). The products were sequenced and confirmed to be the target genes. The transcription level of each key enzyme gene experienced a world of variation from February 2004 to July 2007 (Fig. 3). By real-time RT-PCR it was concluded

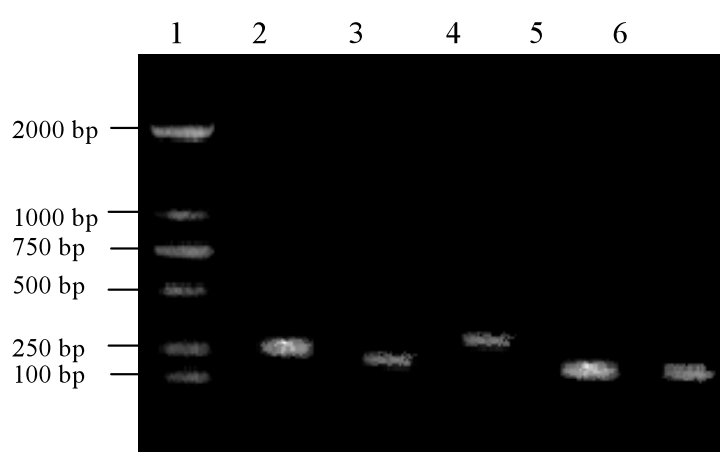

Fig. 2. Ethidium bromide-stained agarose gel showing RT-PCR products of: 1, 2000 bp DNA ladder; 2, hmgr; 3, dbat; 4, ggpps; 5, 18S r DNA; 6, dxr.

\begin{tabular}{lccc}
\hline Sample & \multicolumn{2}{c}{ Absorbency ratio } & Total RNA [ $\mu \mathrm{g} / \mathrm{g}$ FW] \\
\cline { 2 - 3 } & $A_{260 /} A_{230}$ & $A_{260 /} A_{280}$ & \\
\hline CTAB method & $1.47(0.11)$ & $1.56(0.18)$ & $181(58)$ \\
MT method & $1.81(0.15)$ & $1.92(0.24)$ & $245(71)$ \\
\hline
\end{tabular}

Table II. Spectrophotometric readings used to evaluate the RNA quantity and quality.

Results are expressed as the mean of 3 samples (standard deviation). 


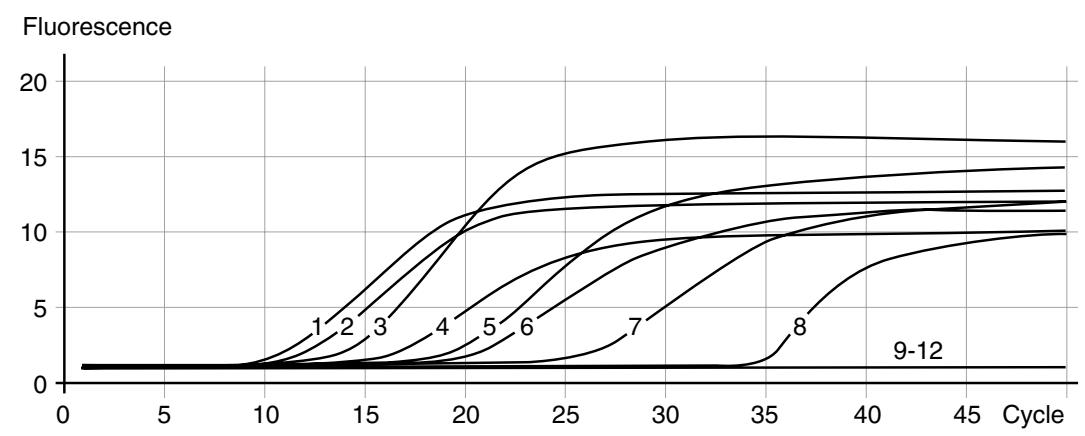

Fig. 3. Expression profile of ggpps, $d x r$, hmgr and $d b a t$ from TS and TL samples by quantitative real-time PCR: 1, ggpps of TS sample; 2, $d x r$ of TS sample; 3, hmgr of TS sample; 4, dbat of TS sample; 5, ggpps of TL sample; 6, dxr of TL sample; 7, hmgr of TL sample; 8, dbat of TL sample; $9-12$, negative control of ggpps, dxr, hmgr and dbat, respectively.

that the expression levels of the genes in TS samples were apparently higher that those in TL samples (Table III).

Table III. Relative transcript levels of four genes from TS and TL samples.

\begin{tabular}{lccc}
\hline Gene & ${ } \triangle \mathrm{CT}$ & \multicolumn{2}{c}{ Relative transcritpt level (\%) } \\
\cline { 3 - 4 } & & $\mathrm{TL}$ & $\mathrm{TS}$ \\
\hline ggpps & $-9.2( \pm 0.3)$ & 100 & $2^{9.2( \pm 0.3)}$ \\
dxr & $-9.3( \pm 0.2)$ & 100 & $2^{9.3( \pm 0.2)}$ \\
hmgr & $-13.2( \pm 0.3)$ & 100 & $2^{13.2( \pm 0.3)}$ \\
dbat & $-16.1( \pm 0.4)$ & 100 & $2^{16.1( \pm 0.4)}$ \\
\hline
\end{tabular}

\section{Quantification of paclitaxel by HPLC}

The paclitaxel production of Taxus media cv. Hicksii cell culture notably decreased from February 2004 to July 2007. In addition, it can be noted that the amount of other taxanes and unknown secondary metabolites also decreased during the course.

\section{Discussion}

Phenolic compounds are readily oxidized and covalently linked with quinones, and bind nucleic acids (Malnoy et al., 2001). Polysaccharides can coprecipitate with RNA in low ionic strength buffers (Liu et al., 1998), leading to poor-quality RNA or no RNA at all. PVP has a strong ability to bind with phenolics, inhibiting oxidation and preventing quinone binding with RNA. Mercaptoethanol can interrupt the disulfide bridge of polyphenol oxidase and prevent polyphenol from oxidation. Addition of $\mathrm{NaAc}$ during precipitation can efficiently eliminate the intervention of polysaccharides. Our data suggested that RNA extracted with the MT method provide robust template for the reverse transcription reaction.

DBAT and GGPP are key enzymes determining the downstream and upstream regulation level, respectively (Walker and Croteau, 2000; Liao et al., 2005). Transcript levels of dbat and ggpps in TL cells were much lower than those in TS cells, which may account for the decrease of the paclitaxel content of Taxus cell. HMGR is the first key enzyme in the classical mevalonate pathway and DXR the second in the non-mevalonate pathway. Their expression levels in TL cells were much lower than those in TS cells. The result suggested that the decreasing tendency of the expression profiles does not happen only on the key enzyme genes which are closely related with paclitaxel biosynthesis, but also on the early metabolic pathway before the biosynthesis of IPP. HPLC analysis showed that the amounts of all other secondary metabolites besides paclitaxel decreased.

Many strategies are now focusing on the transcriptional regulation of key enzyme genes involved in the paclitaxel biosynthesis, such as inducing Taxus cells by various elicitors and precursor feeding (Ketchum et al., 2007; Wang et al., 2007; Zhang et al., 2007). However, these strategies can not solve the problem of gradual paclitaxel loss during long-term subculture. Once a newly established paclitaxel cell line losses its high productivity characteristic after continuous subcultures, it is difficult to recover it by simple ma- 
nipulation on the metabolic regulation. For this reason, more emphasis should be put on the conservation of high-yield cell lines and on elucidating the mechanism underlying the somaclonal variation that is responsible for the gradual loss of secondary metabolites after continuous subcultures.
Amoroso M. G., Longobardo L., and Capparelli R. (2004), Real time RT-PCR and flow cytometry to investigate wheat kernel hardness: Role of puroindoline genes and proteins. Biotechnol. Lett. 26, 1731-1737.

Chau M., Jennewein S., Walker K., and Croteau R. (2004), Taxol biosynthesis: Molecular cloning and characterization of a cytochrome $\mathrm{P} 450$ taxoid $7 \beta$-hydroxylase. Chem. Biol. 11, 663-672.

Ketchum R. E. B., Horiguchi T., Qiu D., Williams R. M., and Croteau R. B. (2007), Administering cultured Taxus cells with early precursors reveals bifurcations in the taxoid biosynthetic pathway. Phytochemistry 68, 335-341.

Kim B. J., Gibson D. M., and Shuler M. L. (2004), Effect of subculture and elicitation on instability of taxol production in Taxus sp. suspension cultures. Biotechnol. Prog. 20, 1666-1673.

Liao Z., Gong Y., Kai G., Zuo K., and Chen M. (2005), An intron-free methyl jasmonate inducible geranylgeranyl diphosphate synthase gene from Taxus media and its functional identification in yeast. Mol. Biol. 39, $11-17$.

Liu J., Goh C., Lou C., Liu P., and Pua E. (1998), A method for isolation of total RNA from fruit tissues of $B a$ nana. Plant Mol. Biol. Rep. 16, 1-6.

Malnoy M., Reynoird J. P., Mourgues F., Chevreau E., and Simoneau P. (2001), A method for isolating total RNA from pear leaves. Plant Mol. Biol. Rep. 19, 69a-69f.

Martin K. P. and Pradeep A. K. (2003), Simple strategy for the in vitro conservation of Ipsea malabarica, an endemic, endangered orchid of the Western Ghats of Kerala, India. Plant Cell Tissue Organ Culture 74, 197-200.

Nims E., Dubois C. P., Roberts S. C., and Walker E. L. (2006), Expression profiling of genes involved in paclitaxel biosynthesis for targeted metabolic engineering. Metab. Eng. 8, 385-394.
Pyo S., Park H., Song B., Han B., and Kim J. (2004), A large-scale purification of paclitaxel from cell cultures of Taxus chinensis. Process Biochem. 39, 1985-1991.

Rubluoa A., Hernandezb T. M., Duvalal K., Vargasc A., and Guzman J. M. (2002), Auxin-induced morphogenetic responses in long-term in vitro subcultured Mammillaria san-angelensis Sánchez-Mejorada (Cactaceae). Sci. Hortic. 95, 341-349.

Smykal P., Valledor L., Rodriguez R., and Griga M. (2007), Assessment of genetic and epigenetic stability in long-term in vitro shoot culture of pea (Pisum sativum L. ). Plant Cell Rep. 26, 1985-1998.

Trejo-Tapia G., Balcazar-Aguilar J. B., Martínez-Bonfil B., Salcedo-Morales G., Jaramillo-Flores M., ArenasOcampo M. L., and Jiménez-Aparicio A. (2008), Effect of screening and subculture on the production of betaxanthins in Beta vulgaris L. var. 'Dark Detroit' callus culture. Innova. Food Sci. Emerg. Technol. 9, $32-36$.

Walker K. and Croteau R. (2000), Molecular cloning of a 10-deacetylbaccatin III-10-O-acetyl transferase cDNA from Taxus and functional expression in Escherichia coli. Proc. Natl. Acad. Sci. USA 97, 583587.

Wang Y., Wu J., and Yuan Y. (2007), Salicylic acid-induced taxol production and isopentenyl pyrophosphate biosynthesis in suspension cultures of Taxus chinensis var. mairei. Cell Biol. Int. 31, 1179-1183.

Whitmer S., Canel C., van der Heijden R., and Verpoorte R. (2003), Long-term instability of alkaloid production by stably transformed cell lines of Catharanthus roseus. Plant Cell Tissue Organ Culture 74, 73-80.

Zhang C. and Fevereiro P. S. (2006), The effect of heat shock on paclitaxel production in Taxus yunnanensis cell suspension. Biotechnol. Bioeng. 96, 506-514.

Zhang C. H., Fevereiro P. S., He G., and Chen Z. (2007), Enhanced paclitaxel productivity and release capacity of Taxus chinensis cell suspension cultures adapted to chitosan. Plant Sci. 172, 158-163. 